\title{
РОЗВИТОК ІТ-АУТСОРСИНГУ ТА ЙОГО ВПЛИВ НА ЕКОНОМІКУ УКРАÏНИ
}

\section{IT OUTSOURCING DEVELOPMENT AND ITS IMPACT ON THE ECONOMY OF UKRAINE}

\author{
Двуліт Зоряна Петрівна \\ доктор економічних наук, професор, \\ Національний університет «Львівська політехніка» \\ ORCID: https://orcid.org/0000-0002-2157-1422 \\ Налутка Павло Васильович \\ студент ОКР «Магістр», \\ Національний університет «Львівська політехніка» \\ ORCID: https://orcid.org/0000-0002-8842-423
}

\author{
Dvulit Zoriana, Nalutka Pavlo \\ Lviv Polytechnic National University
}

\begin{abstract}
У данній статті проаналізовано ринок IT аутсорсингу в Україні, виділено найбільш поширені серед українських компаній види аутсорсингу, розглянуто основні переваги та недоліки аутсорсингу, як моделі ведення бізнесу в сучасних умовах господарювання. Проведено аналіз динаміки розвитку IT-аутсорингу в Україні, а саме, було розглянуто часту IT у ВВП України з 2011 по 2020 роки, роль і місце України на світовому ринку цих послуг, виділено ключові тенденції та напрямки розвитку аутсорсингу, розглянуто топ найбільших роботодавців у ссрері аутсорсингу в Україні. Зроблено висновки, щодо можливостей, викликів та перпектив використання аутсорсингу українськими компаніями. Розроблено рекомендації, щодо збільшення рівня привабливості України для великих іноземних компаній.
\end{abstract}

Ключові слова: аутсорсинг, сфрера IT, тенденції розвитку, економічі наслідки.

В данной статье проанализирован рынок IT аутсорсинга в Украине, выделены наиболее распространенные среди украинских компаний виды аутсорсинга, рассмотрены основные преимущества и недостатки аутсорсинга как модели ведения бизнеса в современных условиях хозяйствования. Проведен анализ динамики развития IT-аутсоринга в Украине, а именно, было рассмотрено часть IT в ВВП Украины с 2011 по 2020 г., роль и место Украины на мировом рынке этих услуг, выделены ключевые тенденции и направления развития аутсорсинга, рассмотрены топ крупнейших работодателей в сорере аутсорсинга в Украине. Сделаны выводы о возможностях, вызовах и перспективах использования аутсорсинга украинскими компаниями. Разработаны рекомендации по увеличению уровня привлекательности Украины для крупных иностранных компаний.

Ключевые слова: аутсорсинг, сорера IT, тенденции развития, экономические последствия.

A large amount of well-qualified IT developers in different developing countries, low salaries in the internal markets of these countries, restrictions due to the COVID-19 pandemic, and high level of technological progress has encouraged a lot of big companies to create outsourcing companies in different countries all over the world. Ukraine belongs to countries that are attractive to foreign companies in terms of developing business. It has a list of positive consequences for the Ukrainian economy. For instance, these companies have already created significant opportunities for both external and inland employees. Therefore, in this paper, we examine and estimate the real impact of IT outsourcing on the economics of Ukraine. The study aims to analyze the current situation in the IT-outsourcing market in Ukraine. To determine trends, prominent advantages, and drawbacks of such business activity, analyze Ukraine's most significant IT outsourcing companies. And show the influence of outsourcing on Ukraine economics based on examples of these companies and their experience. In this article, we can highlight a couple of definitions and the main types of outsourcing. This article analyzes the advantages and disadvantages of outsourcing as a business model. Besides, it explores the dynamics of the IT-sphere part in the GDP of Ukraine during the period between 2011-2020. The top 10 of the biggest outsourcing companies in Ukraine were investigated. In addition, the perspectives of IT outsourcing for Ukraine economics and how to improve the legislation to attract more foreign companies were detected. The IT sphere is noteworthy and has significant perspectives for development. To fulfill 
outsourcing potential in Ukraine, it is necessary to create a firm legal framework that would regulate such activity and, in particular, guarantee copyright protection. Besides, the foreign partners are interested in cooperating with companies implementing the quality control system and well-developed corporate social responsibility. In addition, the significant trends in the IT-outsourcing sector during the last ten years are highlighted. Based on all of the above, recommendations are made on attracting foreign companies to spread into the Ukrainian market. These will help to increase the part of IT in the GDP of Ukraine and create more decent workplaces for Ukrainian IT developers.

Keywords: outsourcing, IT sphere, development trends, economic consequences.

Постановка проблеми. В умовах сьогодення процеси глобалізації, впровадження новинок науково-технічного прогресу, необхідність переведення частини працівників на дистанційний режим праці через пандемію вірусу COVID-19 та зростання важливості інтелектуальної праці дозволяють та стимулюють все більше і більше великих компаній шукати та впроваджувати у свою діяльність нові методи та підходи до ведення бізнесу. Це у свою чергу, призвело до виникнення попиту на послуги аутсорсингу. Висока якість, значна кількість трудових ресурсів, а також низький рівень заробітної плати на внутрішньому ринку України приваблює багато іноземних компаній, оскільки, це дозволяє скорочувати витрати на оплату праці, а також залучати кваліфрікованих працівників. В умовах не надто великого попиту на послуги 3 розробки IT продуктів та надання послуг інфрормаційного забезпечення на внутрішньому ринку України, прихід іноземних компаній, які зацікавленні у послугах українських орахівців дозволяє забезпечувати велику кількість робочих місць з високим рівнем оплати праці.

Аналіз останніх досліджень і публікацій. Питаннями лослідження проблеми аутсорсингу, як одного з способів ведення бізнесу, займались такі зарубіжні вчені: А. Маккарті [1], С. Розенберг [2], Б. Зімерман [3], А. Фраззето [4], С. Лор [5]. Українські науковці займались дослідженням перспектив розвитку та можливостей аутсорсингу в Україні, а також впливу аутсорсингу на економіку України. Серед них варто виділити роботи О. В. Ільєнко, Н. К. Мороз [6], В. В. Красношапка та І. І. Трохимець [7].

3 огляду на глобалізаційні процеси, розвиток сучасних технологій, а також необхідність мобільних робочих місць в сорері IT аутсорсинг набирає все більшої популярності, як вектор ведення бізнесу.

Формулювання цілей дослідження. Метою дослідження $€$ здійснення аналізу ринку IT аутсорсингу України в сучасних умовах господарювання. 3 огляду на вказану мету, поставленні наступні завдання:

- аналіз тенденцій, що спостерігаються у сорері IT в Україні;
- визначення структури та рівня попиту іноземних компаній на українських IT фрахівців;

- аналіз структури ВВП України за 2011-2020 рр. та виокремлення частки IT галузі у ньому;

- формування практичних рекомендацій щодо збільшення привабливості України для великих світових компаній та покращення якості надання аутсорсингових послуг.

Виклад основного матеріалу дослідження. Розвиток явища IT-аутсорсингу В Україні вже вніс та продовжує вносити велику кількість позитивних явищ, які сприяють досягненню низки макроекономічних ефектів. Вони в свою чергу можуть призвести до фрормування нових тенденцій розвитку економіки країни. IT-аутсорсинг має прямий вплив на структуру ринку праці та динаміку платіжного балансу, опосередковані ефекти розвитку IT-аутсорсингу призводять до збільшення внутрішнього попиту на споживчому ринку, сприяють нівелюванню розшарування населення та фрормують середній клас, створюють сприятливі умови для розширення платоспроможного попиту на послуги охорони здоров'я та зміцнення фрінансової безпеки держави. Тому, есрективна державна політика, яка сприятиме розвитку IT-аутсорсингу дозволить розкрити потенціал даної галузі, що у майбутньому сприятиме зростанню економіки України.

Сучасний етап розвитку технологій дає можливість працювати з будь-якого куточка світу, тому, зараз існує безліч процесів, які можливо успішно перевести на аутсорсинг, зокрема: бухгалтерський облік, IT-забезпечення, програмування, системне адміністрування, юридичні послуги, пошук і найм працівників, SMM та кол-центри.

Згідно з визначенням Bloomberg Financial Glossary [8], аутсорсинг - це купівля значної кількості проміжних компонентів у зовнішніх постачальників. Deardorff's Glossary of International Economics [9] визначає аутсорсинг, як: здійснення сторонньою організацією виробничої діяльності, яка раніше виконувалась у межах компанії.

Дж. Хейвуд визначив поняття аутсорсингу, як переведення одного або декілька підроз- 
ділів підприємства і всіх пов'язаних із ними активів в організацію постачальника послуг, що пропонує надання певної послуги протягом визначеного часу за певною ціною [10].

Аутсорсинг полягає у делегуванні частини діяльності зовнішньому підряднику. Послуги аутсорсингу поділяються на локальні та офршорні. Локальний аутсорсинг означає надання послуг у країні замовника, а офршорний за її межами. Основою офшорного аутсорсингу є різниця в розмірах оплати праці в країні виконавця та замовника.

Найпоширенішими видами офршорного IT-аутсорсингу $€$ [11]:

- виведення у іншу країну другорядних служб підтримки інфрраструктури (ITO-infrastructure technology outsourcing);

- виведення у іншу країну некритичних для бізнесу процесів, що вимагають великого обсягу некваліфрікованої праці (BPO-business process outsourcing);

- розробка програмного забезпечення на замовлення (Software R \& D, Application Development).

Великою популярністю серед українських підприємств користується офшшорний аутсорсинг. Цьому сприяє низький рівень заробітної плати на внутрішньому ринку, та висока кваліфікація вітчизняних фрахівців. Ці два фрактори значно посилюють конкурентні позиції на ринку послуг з розробки програмних продуктів.

Аналізуючи аутсорсинг, як явище, йому властиві позитивні та негативні сторони.

До основних переваг, які отримують підприємства, відносять [12]:

- менші витрати на обслуговування компанії;

- зниження ризиків через передачу великої кількості процесів компанії виконавцю;

- орінансова гнучкість;

- можливість залучення інтелектуального капіталу;

- отримання умов для проведення маштабниз транморормаційних змін;

Основні недоліки IT-аутсорсингу [13]:

- часткова втрата контролю над діяльністю компанії;

- зниження рівня безпеки, залежність від замовника або виконавця послуг;

- зменшення рівня продуктивності праці власного персоналу;

- порушення чи зловживання інтелектуальною власністю.

Проте, не всі процеси компанії можна віддати на аутсорсинг. За даними дослідженя консалтингової компанії Асассе на аутсорсинг найчастіше віддаються такі процеси [14]:
- ІТ-послуги 40,5\%;

- логістика 35,1\%;

- процес закупівлі 27\%;

- маркетингові бізнес-процеси 21,6\%;

- рекрутинг 18,9\%;

- бухгалтерський облік 13,5\%;

- розрахунок заробітної плати 13,5\%;

- обробка та систематизація інсрормації 8,1\%;

- аутсорсинг медпредставників 8,1\%;

- кадрове діловодство та адміністрування $5,4 \%$;

- різні адміністративні функції 2,7\%.

За даними International Association of Outsourcing Professionals (IAOP) багато українських роботодавців потрапили у рейтинг топ-100 постачальників аутсорсингових послуг [14]:

- SoftServe (м. Львів - близько 4500 працівників);

- Ciklum (м. Київ - близько 2000 працівників);

- Infopulse (м. Київ - близько 1500 працівників);

- ELEKS (м. Львів - близько 1000 працівників);

- Sigma Software (м. Харків - близько 800 працівників);

- Intellias (м. Львів - близько 1500 працівників);

- Miratech (м. Київ - близько 700 працівників);

- N-iX (м. Львів - близько 800 працівників);

- Innovecs (М. Київ - близько 400 працівників);

- AMC Bridge (м. Дніпро - близько 300 працівників);

- Softengi (м. Київ - близько 200 працівників);

- Program-Ace (м. Харків - близько 100 працівників).

World Bank, PwC i IT Ukraine [15] провели дослідження українського ринку IT. Згідно до цих досліджень, характеристика українського ринку IT-аутсорсингу $€$ наступною: в Україні налічується понад 1600 компаній, що надають послуги IT, кількість фрахівці становить близько 185000 осіб. Функціонує близько 4000 аутсорсингових компаній. Українські компанії мають розвинену мережу зв'язків, а саме близько 100 компаній зі списку Fortune (рейтинг великих світових компаній) $€$ клієнтами українських IT-срірм. Інфрормаційнокомунікаційні технології (IKT) - третя за величиною галузь, на яку припадає $20 \%$ всього українського експорту послуг.

Світові великі компанії, які зацікавленні в українських фрахівцях відкривають свої фрілії здебільшого у великих містах України. За даними Stack Overflow [16], у Києві нара- 
ховується близько 68500 розробників ПЗ, що становить $37 \%$ усього українського пулу IT-фрахівців. Львів $€$ другим за величиною IT-центром в Україні. У місті працюють понад 20000 IT-фрахівців і близько 317 IT-компаній, більшість з яких надають послуги аутсорсингу програмного забезпечення клієнтам в США і Західній Європі.

Валовий внутрішній продукт є одним з ключових показників в економіці країни. На рис. 1 наведено порівняльні чатски перебної промисловості, сільського господарства, видобувної промисловості та IT. Частка IT-галузі в українській економіці становила 4,9\% ВВП у 2020 році та має зростаючу динаміку.

Згідно з рис. 1, за останні 10 років, частка IT галузі зростає та досягнула своїх найбільших значень у 2020 році. У грошовому вираженні, обсяг ВВП у IT галузі зріс з 34,3 млрд грн. у 2011 році до 187 млрд грн. у 2020 році.

Аутсорсинг в Україні вже займає важливі позиції у розвитку та покращенні загальної економічної ситуації. Дану сфреру варто розглядати, як таку, яка має значний потенціал та перспективи розвитку, особливо в умовах пандемії. Однак для цього українські аутсорсингові компанії мають відповідати обов'язковим вимогам європейського ринку. В Україні немає чіткої законодавчої бази, яка $б$ регулювала діяльність пов'язану з аутсор- сингом. Існують лише законодавчі вимоги, які стосуються захисту авторських прав та персональних даних. Важливими для іноземних партнерів $€$ вимоги про наявність систем контролю якості та дотримання корпоративної соціальної відповідальності. Зокрема, необхідно створити більш жорсткі та прозорі інструменти контролю за дотриманням авторських прав. Вся продукція, що виходить, як на український так і на іноземні ринки має бути захищена від несанкціонованого відтворення.

Необхідною $€$ наявність системи управління якістю. Більшість європейських та американських споживачів зацікавленні в послугах компаній, які мають систему управління якістю. Така система свідчить про хорошу організацію діяльності компанії та означає, що компанія здатна забезпечити необхідну якість обслуговування.

Корпоративна соціальна відповідальність - це ще одна додаткова, однак важлива для європейських партнерів вимога. Вони бажають вести справи із компаніями, які відповідальні не тільки за свої продукти чи послуги, а і за дотримання прав споживачів, прав людини, відповідальні за освіту та навчання персоналу, умови праці та турботу про навколишнє середовище.

Висновки. Дослідження IT-аутсорсингу на українському ринку свідчить про високу

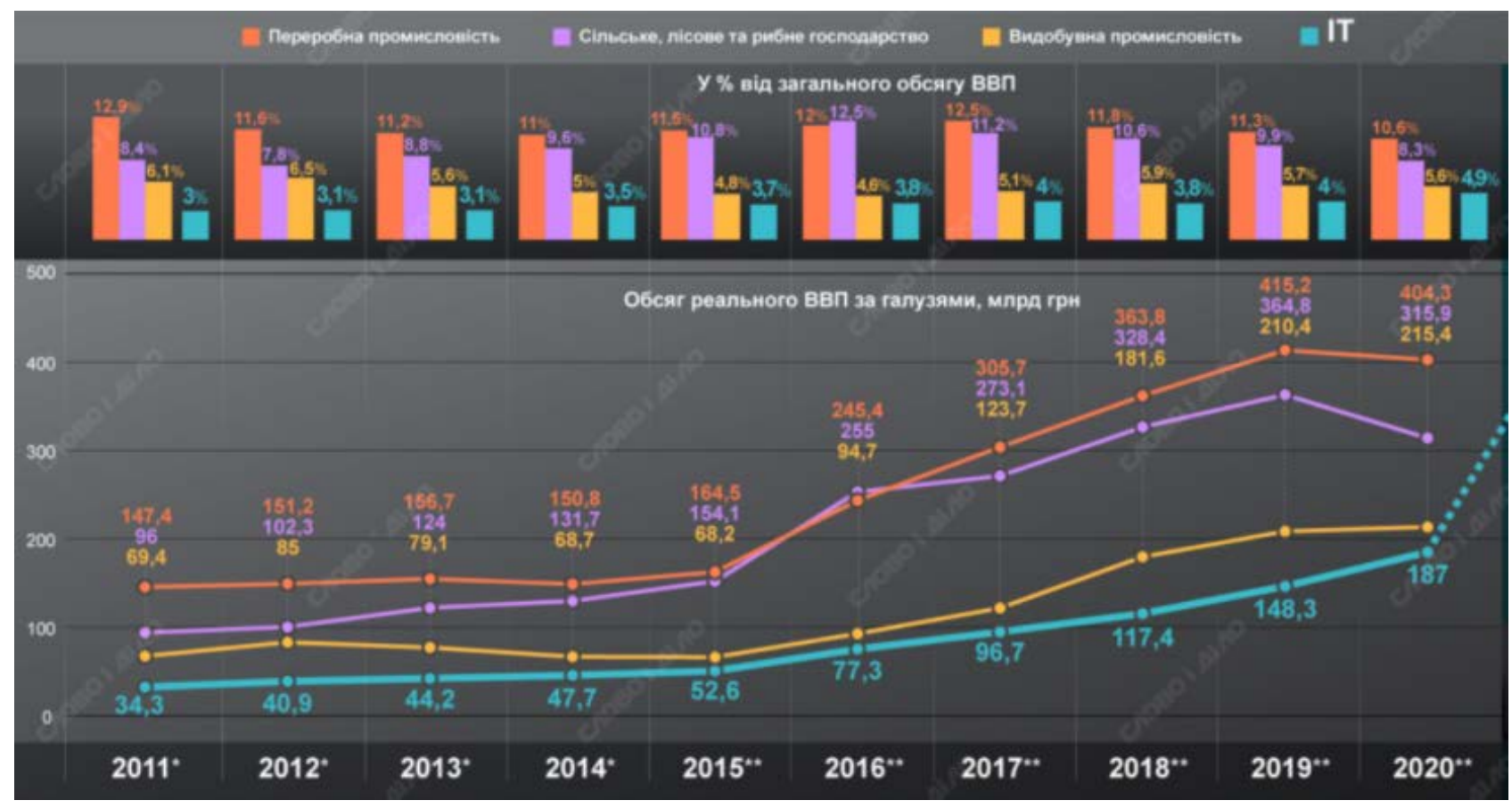

Рис. 1. Порівняльна частка IT сектору у ВВП України за 2011-2020 pp. відносно переробної промисловості сільського господарства та видобувної промисловості Джерело: [17] 
популярність такої моделі ведення бізнесу, а також про затребуваність українських фрахівців серед іноземних IT компаній. Основними фракторами, що впливають на фрормування таких тенденцій $є$ велика кільстість кваліфікованих працівників в Україні, низький рівень заробітної плати на внутрішньому ринку, а також зростанння необхідності дистанційної роботи в умовах пандемії.

Було визначено основні види аутсорсингу, найпопулярнішим, для компаній присутніх на українському ринку, є офшшорний аутсорсинг. Огляд літературних джерел за даною у роботі тематикою, дав змогу виокремити недоліки та переваги аутсорсингу, як способу ведення бізнесу. Основними перевагами $є$ економія на заробітній платі та доступ до інтелектуального капіталу. До сновних недоліків відносяться втрата повного контролю над компанією та залежність від аутсорсера.

В Україні присутні компанії, які входять у топ-100 постачальників аутсорсиноових послуг. Найбльшими з них $є$ - SoftServe, Ciklum та Infopulse. Лише у них задіяно близько 8000 працівників.

Дослідження ринку IT аутсорсингу показало, що в Україні існує близько 4000 аутсорсингових компаній, а прогнозована кількість працівників становить 185000 осіб. Основними центрами IT-аутсорсингу є Київ та Львів.

Аналіз структури ВВП України показав, що часта IT має тенденцію до зростання. У 2011 році вона становили $3 \%$ у загальному ВВП, а у першому кварталі 2021 року - 4,9\%.

Відповідно до вищенавиденого, можна зробити висновок, що IT сфрера $€$ вартою уваги та має значні перспективи. Для розкриття потенціалу аутсорсингу в Україні необхідно створити чітку законодавчу базу, яка регулювала б таку діяьність, зокрема гарантуватила захист авторськихправ. Також, іноземні партнери зацікавлені у співпраці з компаніями, у яких запроваджена система управління якістю та добре розвинена корпоративна соціальна відповідальність.

\section{СПИСОК ВИКОРИСТАНИХ ДЖЕРЕЛ:}

1. Ian McCarthy, Angela Anagnostou. "The impact of outsourcing on the transaction costs and boundaries of manufacturing". International Journal of Production Economics. 2004. P. 61-71.

2. Stuart Rosenberg. The Global Supply Chain and Risk Management. 2018. ISBN 978-1631579592

3. Ben Zimmerman. "What Are the Benefits of In-Housing Versus Outsourcing?" Forbes. 2019.

4. Anna Frazzetto. "Outsourcing In The New Normal: Three Trends Reshaping The Global Industry". Forbes.

5. Steve Lohr. "Hot Spot for Tech Outsourcing: The United States". URL: https://NYTimes.com

6. Ільєнко О.В., Мороз Н.К. Аналіз ринку ІТ-аутсорсингу в Україні. Науковий вісник Херсонського державного університету. 2014. 159 c.

7. Красношапка В.В., Трохимець І.І. Аутсорсинг та його застосування на підприємствах Українии. Ефективна економіка. 2015. ISSN 2307-2105

8. Bloomberg. URL: https://www.bloomberg.com/ (дата звернення: 25.11.2021).

9. Deardorff A. (2014) Terms of Trade: Glossary of International Economics. 2nd ed. World Scientific Publishing Company.

10. Хейвуд Дж.Б. Аутсорсинг: в пошуках конкурентних переваг. Москва : видавничий дім "Вільямс", 2004.

11. Губина Л.В. Информационные технологии в бизнесе в настоящее время. Проблемы науки. 2018. № 4(28). С. $75-76$.

12. Дайнеко Є., Оленюк А. Аутсорсингові та аутстафрінгові послуги: вимоги європейського ринку. URL: https://everlegal.ua/autsorsyngovi-ta-autstafingovi-poslugy-vymogy-evropeyskogo-rynku

13. Гребешкова О.М. Становлення IT-аутсорсингу в Україні: огляд через призму світової практики. Формування ринкової економіки : зб. наук. пр. Київ, 2011. Вип. 25. С. 305-313.

14. Консалтингова компанія ACCACE. URL: https://accace.com/

15. Скільки грошей приносить Україні IT індустрія. URL: https://dyvys.info/2019/11/07/skilky-groshej-prynosytukrayini-it-industriya/

16. Stack overflow. URL: https://stackoverflow.com/

17. Державна служба статистики України : веб-сайт. URL: http://www.ukrstat.gov.ua/

\section{REFERENCES:}

1. Ian McCarthy, Angela Anagnostou (2004) "The impact of outsourcing on the transaction costs and boundaries of manufacturing". International Journal of Production Economics, pp. 61-71.

2. Stuart Rosenberg (2018) The Global Supply Chain and Risk Management. ISBN 978-1631579592 
3. Ben Zimmerman (2019) "What Are the Benefits of In-Housing Versus Outsourcing?" Forbes.

4. Anna Frazzetto. "Outsourcing In The New Normal: Three Trends Reshaping The Global Industry". Forbes.

5. Steve Lohr. "Hot Spot for Tech Outsourcing: The United States". Available at: https://NYTimes.com

6. Il'ienko O.V., Moroz N.K. (2014) Analiz rynku IT-autsorsynhu v Ukraini. Naukovyj visnyk Khersons'koho derzhavnoho universytetu", p. 159. (in Ukrainian)

7. Krasnoshapka V.V., Trokhymets' I.I. (2015) Autsorsynh ta joho zastosuvannia na pidpryiemstvakh Ukrainyy. Efektyvna ekonomika. ISSN 2307-2105 (in Ukrainian)

8. Bloomberg. Available at: https://www.bloomberg.com

9. Deardorff A. (2014) Terms of Trade: Glossary of International Economics. 2nd ed. World Scientific Publishing Company.

10. Khejvud Dzh.B. (2004) Autsorsynh: v poshukakh konkurentnykh perevah. Moscow: vydavnychyj dim "Vil'iams". (in Ukrainian)

11. Hubyna L.V. (2018) Ynformatsyonnye tekhnolohyy v byznese v nastoiaschee vremia. Problemy nauky, 4(28), 75-76. (in Russian)

12. Dajneko Ye., Oleniuk A. Autsorsynhovi ta autstafinhovi posluhy: vymohy ievropejs'koho rynku. Available at: https://everlegal.ua/autsorsyngovi-ta-autstafingovi-poslugy-vymogy-evropeyskogo-rynku (in Ukrainian)

13. Hrebeshkova O.M. (2011) Stanovlennia IT-autsorsynhu v Ukraini: ohliad cherez pryzmu svitovoi praktyky. Formuvannia rynkovoi ekonomiky: zb. nauk. pr., 25, 305-313.

14. Consulting company ACCACE. Available at: https://accace.com/

15. Skil'ky hroshej prynosyt' Ukraini IT industriia. Available at: https://dyvys.info/2019/11/07/skilky-groshejprynosyt-ukrayini-it-industriyal

16. Stack overflow. Available at: https://stackoverflow.com/

17. Derzhavna sluzhba statystyky Ukrainy. Available at: http://www.ukrstat.gov.ua/ 